\title{
Lógicas comunicacionais da circulação de fake news sobre Covid-19 no WhatsApp
}

Resumo: O texto analisa lógicas comunicacionais presentes em conteúdos falsos e desinformação sobre o coronavírus e a pandemia de Covid-19, disseminados em um grupo de profissionais da saúde, com coleta de dados efetuada entre março e maio de 2020. Para tanto, é desenvolvida uma discussão conceitual sobre fake news e desinformação, bem como a respeito dos modos de circulação e produção de acontecimentos contemporâneos. Analisamos a ocorrência de ondas de dissipação de conteúdos falsos que criam circuitos de acontecimentalização efêmeros, com padrão de orientação de ação, simulação do jornalismo e recriação de audiência fora da mídia. A associação entre os conceitos de fake news e desinformação permite contemplar circuitos correlatos, como confusão, fatalismo e ordenação da ação pública.

Palavras-chave: Fake news; Coronavírus; Desinformação; WhatsApp.

\section{Lógicas comunicacionales de la circulación de fake news sobre Covid-19 en WhatsApp}

Resumen: El texto analiza operaciones de comunicación presentes en contenido falso y desinformación sobre el coronavirus y la pandemia del covid-19, difundidas en un grupo de profesionales de la salud, con recolección de datos realizada entre marzo y mayo de 2020. Por ello, el trabajo presenta una discusión conceptual sobre noticias falsas y desinformación, así como formas de circulación y producción de eventos contemporáneos. Se analiza la ocurrencia de olas de difusión de contenidos falsos que crean circuitos efímeros de eventalización, con un patrón de orientación a la acción, simulación del periodismo y la recreación de una audiencia fuera de los medios. La asociación entre los conceptos de fake news y desinformación nos permite contemplar circuitos relacionados como la confusión, el fatalismo y la ordenanza de acción pública.

Palavras clave: Fake news; Coronavirus; Desinformación; WhatsApp.

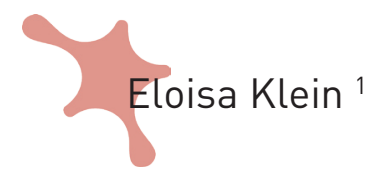

1 Professora da Universidade Federal do Pampa. Doutora em Ciências da Comunicação pela Universidade do Vale do Rio dos Sinos (Unisinos). Graduada em jornalismo pela Universidade Regional do Noroeste do Estado do Rio Grande do Sul (Unijuí). 


\title{
$\gamma_{\text {Rizoma }}$
}

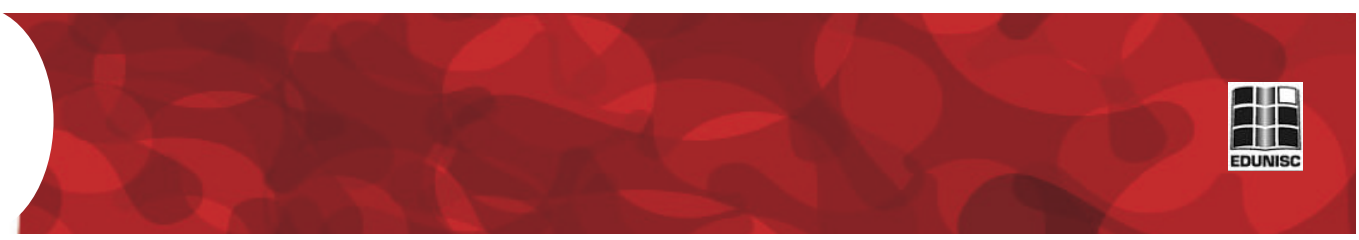

\section{Communicational logics of the fake news circulation about Covid-19 on WhatsApp}

2 Quem é Aleksandr Kogan, o professor por trás do escândalo da Cambridge Analytic, 2018.

\begin{abstract}
The text analyzes communication operations present in false content and misinformation about the coronavirus and the covid-19 pandemic, disseminated in a group of health professionals, with data collection carried out between March and May, 2020. Therefore, the paper presents a conceptual discussion about fake news and misinformation, as well as ways of circulation and production of contemporary events. The occurrence of waves of dissemination of false content that create ephemeral eventalization circuits, with a pattern of action orientation, simulation of journalism and the recreation of an audience outside the media is analysed. The association between the concepts of fake news and misinformation allows us to contemplate related circuits such as confusion, fatalism and public action ordinance. Keywords: Fake news; Coronavirus; Misinformation; Whatsapp.
\end{abstract}

\section{Introdução}

A discussão sobre a disseminação de conteúdos falsos, ou fake news, foi ampliada desde a descoberta das ações da Cambridge Analytica na eleição de Trump, nos Estados Unidos, e no Brexit. A empresa construiu perfis psicológicos de usuários, baseada em páginas curtidas no Facebook e um questionário, que permitiu acesso aos dados de 700 mil pessoas ${ }^{2}$. De acordo com o perfil dos usuários, a empresa passou a designar conteúdos, falsos e verdadeiros, sobre assuntos com os quais as pessoas se sentiam vinculadas ou temas dos quais tinham medo.

Desde a denúncia de tais operações por um ex-funcionário da Cambrigde Analytica, várias ações para contenção de espalhamento de fake news foram perpetradas pelo Facebook, Twitter e Google. Tais medidas não abrangeram o WhatsApp, que serviu para circulação em larga escala de conteúdos falsos, discurso de ódio e propaganda por disparos de mensagens nas eleições presidenciais do Brasil e da Índia. Depois disso, o WhatsApp limitou o número de contatos que poderiam receber mensagens de um mesmo emissor. Porém, estudos indicam que grupos continuaram agindo como multiplicadores de conteúdos (RESENDE et al., 2019).

A discussão pública sobre fake news tomou novo vigor quando, tão rapidamente quanto o espalhamento do coronavírus, começaram a se espalhar boatos sobre surgimento do vírus, curas caseiras, remédios milagrosos, mortos a mais ou a menos - e conspirações políticas. Iniciou-se um debate internacional que tinha em conta o fato de que, 


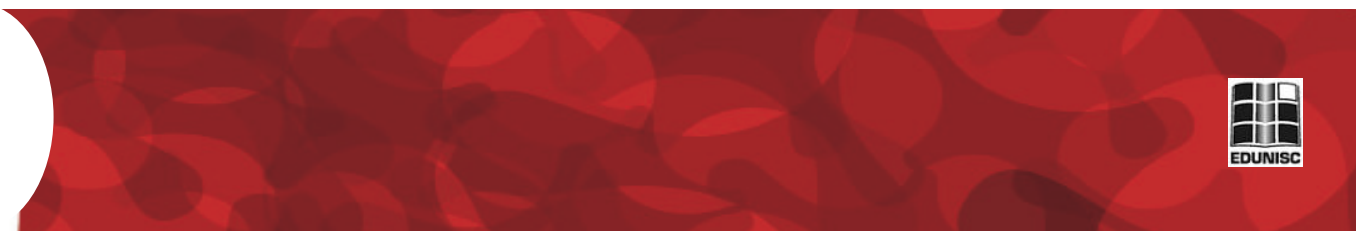

além de ajudar a eleger políticos duvidosos, as fake news eram uma ameaça real à vida dos seres humanos.

Neste texto, analisamos lógicas comunicacionais presentes em conteúdos falsos e desinformação acerca do coronavírus e da pandemia de Covid-19 recebidos em um grupo do WhatsApp composto por profissionais da saúde do Rio Grande do Norte. Apesar do crivo de entrada ser a formação na área da saúde, há uma intensa reverberação de conteúdos falsos, particularmente entre os meses de março e abril de 2020 .

Como tratamos de uma análise focada no presente, realizamos um estudo de publicações jornalísticas sobre a Covid-19 e dos circuitos de desinformação a ela associados. Tal dimensão aciona a perspectiva do jornalismo como um dos modos de conhecimento sobre a realidade, pautado em uma imediaticidade que "é o ponto de chegada, o resultado de todo um processo técnico e racional que envolve uma reprodução simbólica" (GENRO FILHO, 1987, p. 58-59). Neste processo, o jornalismo pode "revelar aspectos da realidade que os outros modos de conhecimento não são capazes de revelar", em parte porque "não apenas reproduz o conhecimento que ele próprio produz, reproduz também o conhecimento produzido por outras instituições sociais" (MEDITSCH, 1997, p. 3).

Tecemos reflexões sobre o conceito de fake news e suas relações com circuitos contemporâneos de acontecimentalização, para então efetuar a análise de um conjunto de materiais recebidos pelo WhatsApp. Não estivemos nos grupos sem autorização, obtivemos material que não revela a identidade, a partir de um informante que é membro do grupo. O grupo dos profissionais da saúde tem membros majoritariamente vinculados à cidade de Natal, no Rio Grande do Norte. Foi solicitado que o informante enviasse qualquer conteúdo de autenticidade não confirmada sobre coronavírus que recebesse nos grupos. Foi considerado o período de 15 de março a 5 de maio.

\section{Perspectivas acerca do conceito de fake news e desinformação}

Embora o termo fake news seja contestado por sites especializados em checagem jornalística e órgãos internacionais que tentam regular a matéria, é preciso admitir que este termo se tornou de amplo uso popular. Madeleine de Cock Buning (VALENTE, 2019), diretora do grupo de especialistas em desinformação da Comissão Europeia, analisa que "desinformação" é um termo mais adequado, já que com o passar dos anos, o termo fake news foi apropriado por pessoas que querem desqualificar qualquer coisa fora de seu campo ideológico. O termo "desinformação" passou a ser adotado por empresas de 


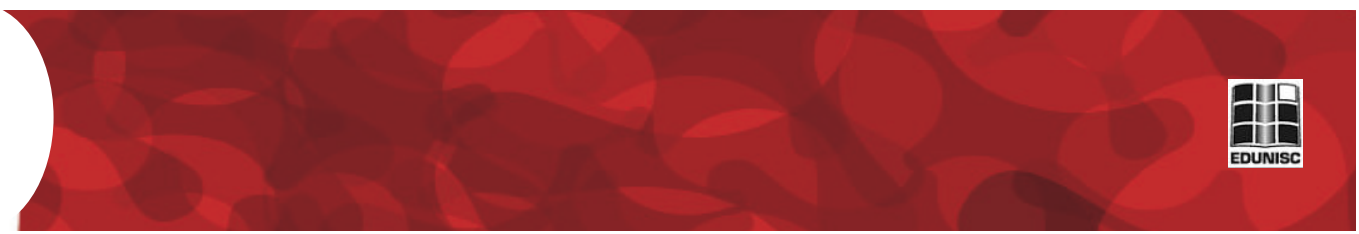

checagem, como a Lupa (INSTITUTO MILLENIUM, 2020), que analisa as estratégias políticas presentes em tais conteúdos. O termo também passou a ser empregado por empresas de mídia e jornalismo, como Bermúdez (2020), que destaca a necessidade de controlar o compartilhamento, e Estadão (2020), que classifica o momento como "infodemia de desinformação", fazendo um paralelo com o termo da área da saúde "pandemia", conforme proposto pela Organização Mundial de Saúde (OMS).

Apesar da tentativa dos órgãos de regulação em substituir o termo fake news por "desinformação", esta palavra remete, no Brasil, para outro sentido, que é a falta de conhecimento sobre um tema ou mesmo a ignorância. Embora os dicionários oficiais também tratem de desinformação como o ato de desinformar ou espalhar coisas falsas intencionalmente, o sentido de ignorância é mais usual para a palavra desinformação, como é possível observar ao realizar uma busca pelo termo "desinformado" entre as postagens públicas do Facebook: "Só desinformado ou criminoso para votar em alguém assim!"; "Pessoal desinformado leiam, por favor"; "Só fica desinformado quem quer". Por isso, ao buscar por postagens relacionadas ao termo "desinformação" no Facebook e no Twitter, geralmente é possível encontrar empresas jornalísticas e pesquisadores. Deste modo, embora mantenhamos a designação "desinformação", iremos usá-la associadamente a fake news ou conteúdos falsos, pois entendemos que é preciso qualificar o uso do termo.

Allcott, Gentzkow e Yu (2018) compararam postagens consideradas falsas no Facebook e outros sites e detectaram uma redução de fake news após as medidas adotadas para restringir este tipo de conteúdo. Os autores analisam o fato de que as percepções equivocadas e a desinformação são um problema histórico, quando considerados os processos políticos, mas observam que o uso de fake news para fins de convencimento se tornou alarmante a partir das eleições presidenciais dos Estados Unidos, em 2016.

Tandoc Jr, Lim e Ling (2017) elaboraram uma tipologia de definições acadêmicas sobre o termo fake news. Os pesquisadores mencionam que $75 \%$ das pessoas podem confundir acontecimentos com fake news e, embora muitos não façam nada com tais conteúdos, algumas pessoas acabam executando ações, como escolher um candidato para votar.

Uma das conotações dadas ao termo advém das empresas jornalísticas, que qualificavam fake news como conteúdos que copiavam o formato de notícia e apresentavam informações não verificadas e produzidas fora do campo profissional (TANDOC JR; LIM; LING, 2017). Outra conotação do termo tem em conta a intenção de criar desinformação, pois geralmente os autores estão cientes de que 


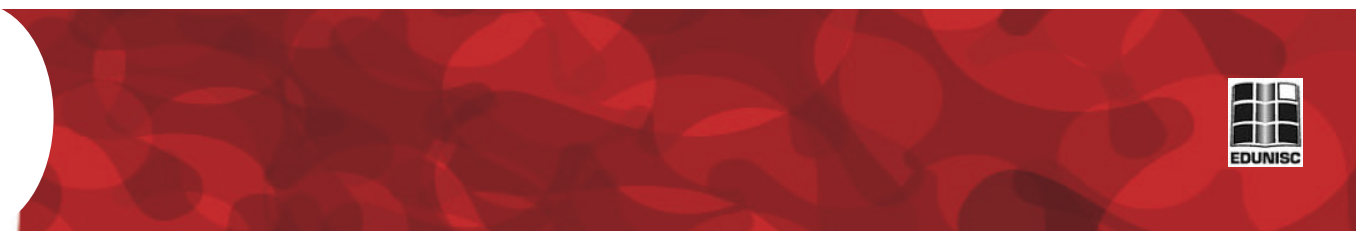

as informações não são verificadas ou verídicas. Um grande número de pessoas clica em manchetes chamativas, embora fantasiosas, e isso faz com que o site que as emite receba um grande número de visitantes e possa gerar grandes quantias em publicidade. Além disso, há o fator de correspondência ideológica, que faz com que pessoas promovam as ideias das quais gostem e tirem crédito das ideias que não gostam.

Outra conotação de fake news empregada no passado levava em consideração a ideia de paródia de jornalismo. Para ilustrar este aspecto, Tandoc Jr, Lim e Ling (2017) retomam o caso da transmissão de Orson Welles, que quis narrar uma fictícia invasão de extraterrestres como entretenimento, mas adotou a forma de uma transmissão radiofônica ao vivo. A partir deste exemplo, podemos pensar que a linguagem do produto predominou sobre a razoabilidade de veridicidade do conteúdo. Apenas se assumiu que uma transmissão ao vivo deveria remeter a fatos. A significativa ocorrência de materiais que simulam o jornalismo ou a reportação do real, dentre os conteúdos falsos, evoca a noção de que a forma é constituidora de sentidos. Textos que parecem manchetes, que simulam linguagem objetiva para tratar de fatos, que trazem citações entre aspas são automaticamente tomados como "verdadeiros".

As mídias sociais criam a possibilidade de que pessoas comuns que evidenciam eventos ou fatos reportem sobre tais situações. Assim, em alguma medida se tornam como testemunhas que a partir de suas publicações, acessam diretamente suas audiências, sem ter que passar pelo jornalismo. Tandoc Jr, Lim e Ling (2017) consideram que quando pessoas escrevem em 140 caracteres, um modelo expandido de manchete, também assumem parcialmente as lógicas do texto jornalístico, efeito que se amplia quando se trata de autoridades ou celebridades escrevendo às suas audiências.

Manuel Chaparro (1996) analisa que há uma assimilação da linguagem jornalística, que é replicada por instituições e agentes públicos - um processo que se amplia quando tais fontes, ao invés de tentar agendar o jornalismo por meio de eventos e releases, criam sua própria comunicação. Assim, embora se tente criar parâmetros para definir o que seria um conteúdo falso e sua diferença com o verdadeiro, há limites colocados pela experiência cotidiana e secular com a mídia, que atribui sentido verdadeiro ao formato noticioso ou ao que é dito por testemunhas de eventos e falas de autoridades. Assim, o que é referendado por uma pessoa próxima, um ídolo ou líder, tende a ser enquadrado como verdadeiro.

Nas mídias sociais, a legitimação de um conteúdo também pode acontecer através da valorização via ranqueamento (o que mais se curte, comenta ou compartilha) e pela sensação de maioria, quando muitas pessoas falam sobre algum tema (TANDOC JR.; LIM; LING, 2017). A circulação de fake news em grande quantidade proporciona 
monetarização, que advém da visitação de sites a partir das manchetes chamativas, que gera exibição de anúncios automáticos. Por causa disso, um grupo de ativistas reunidos sob o título Sleeping Giants passou a atuar com o objetivo de pressionar empresas a retirar anúncios de sites contendo fake news 3 . "O McDonald's, a Claro e a Decathlon, dentre outras empresas, confirmaram por meio de seus perfis oficiais no Twitter terem retirado seus anúncios veiculados em sites de notícias falsas graças ao Sleeping Giants Brasil"'. Os ativistas escolhem um site que publica regularmente conteúdos falsos e iniciam uma campanha para que empresas retirem anúncios (PIRES, 2020). Nos primeiros dias de atuação no Brasil, Sleeping Giants buscaram o cancelamento de anúncios no site Jornal da Cidade Online, "reiteradamente denunciado por agências de checagem pela propagação de notícias falsas"5.

As pressões de usuários e países levaram empresas que gerenciam sites de mídias sociais a buscar ações para controle de propagação de fake news. Twitter e Facebook adotaram a política de apagar conteúdos falsos. No WhatsApp, o controle da circulação de fake news não tem diretrizes claras. Em análise de grupos com link de acesso durante a greve dos caminhoneiros e as eleições presidenciais de 2018, Resende et al. (2019) coletaram milhares de postagens, nas quais observaram a predominância do conteúdo visual, que garante expressivos compartilhamentos. No período eleitoral, $36,2 \%$ das imagens com conteúdo factual continham desinformação, $53,2 \%$ continham conteúdo enganoso e inconclusivo e "apenas 10,6\% foram verificadas como verdadeiras" (RESENDE et al., 2019, p. 7). Para chegar a estas conclusões, os autores compararam os conteúdos com análises de empresas de checagem de fatos. Naquele período, observou-se que as imagens apareciam primeiro na web e depois no WhatsApp, sendo que apenas $6 \%$ do conteúdo aparecia primeiro no aplicativo. Seguindo a análise, é possível pensar que o controle de circulação de conteúdos falsos na internet possa resultar em menor disseminação de fake news no WhatsApp.

A empresa responsável pelo WhatsApp sustenta que o aplicativo não tem por objetivo a formação de audiências (SPAGNUOLO, 2019). Porém, em alguns momentos, se identifica que estratégias de usuários ultrapassam as fronteiras colocadas pela limitação de membros. É o que acontece quando se observa o caso dos "disparos em massa" para "base de usuários" (CAMPOS MELLO, 2018), prática que foi restringida após problemas na eleição do Brasil e de linchamentos na Índia. Outra forma de garantir alcance a milhares de pessoas é a administração de redes de grupos (KLEIN, 2019), quando um núcleo administrativo garante o recebimento e repasse de conteúdos para membros de vários grupos quase ao mesmo tempo. A prática é experimentada de forma espontânea por comunidades, mas também é
3 É um caso de ativismo anônimo pautado pela crítica ao uso econômico da informação, com ação em 2020. Desde maio de 2020, o grupo também passou a atuar no Brasil.

4 ATIVISTAS QUE DENUNCIAM PUBLICIDADE EM SITES EXTREMISTAS CHEGAM AO BRASIL, 2020, online.

5 Ibiden, online. 
orquestrada por empresas. A articulação de audiências garante ampla circulação, sem que haja uma visibilidade pública e consequente discussão sobre características e ética dos conteúdos.

\section{Disseminação de fake news na pandeia de Covid-19}

A Covid-19, causada pelo coronavírus, foi declarada uma pandemia em 11 de março de 2020, pela Organização Mundial de Saúde (OMS). Até 25 de junho ${ }^{6}$, mais de 9,4 milhões de pessoas tiveram confirmação da doença, com 484.155 mortes (OPAS BRASIL, 2020). O primeiro surto aconteceu em Wuhan, na China. A cidade e a província foram fechadas e quatro hospitais foram construídos em poucos dias, com o intuito de evitar que o vírus saísse do território chinês. Porém, ainda em janeiro, casos começaram a aparecer em vários países do mundo, despertando igualmente uma intensa cobertura midiática.

O coronavírus é de uma família de vírus conhecida desde 1937 entre seres humanos (MINISTÉRIO DA SAÚDE, 2020) e pode causar sintomas leves, como os de um resfriado, até sintomas graves, como insuficiência renal e respiratória, ou parada cardíaca. Com o avanço do número de casos, eventos com concentração pública passaram a ser cancelados, aulas suspensas e até atividades comerciais foram interrompidas (BIERNATH, 2020). Tais ações também foram implementadas em 2009, com o surto de H1N1, contudo já existia uma vacina para $\mathrm{H} 1 \mathrm{~N} 1$, que foi disponibilizada pelos governos no mundo todo, reduzindo as medidas de contenção da circulação pública. Na pandemia de Covid-19, não havia qualquer vacina a ser disponibilizada durante o período de circulação do vírus. Sem vacina, a principal forma de reduzir a propagação do vírus foi a restrição da circulação social.

A China fechou o território de Wuhan, onde o surto começou, por 76 dias. Na Itália, segundo epicentro da crise, houve quarentena nacional por dois meses ${ }^{7}$. No Reino Unido, foi criada uma escala de níveis de afetação pelo vírus, de 1 a 5 e, quanto mais baixa, maior o relaxamento da quarentena, que ficou estendida até junho de 2020 (MIGUEL, 2020). Nos Estados Unidos, os entes federados criaram regulações específicas, mas os estados mais populosos, como Nova Iorque e Califórnia, tiveram quarentenas restritivas. Porém, a ausência de resposta coesa do governo federal e a inexistência de um sistema de saúde pública levaram o país a registrar cem mil mortes até maio de 2020 (BBC NEWS, 2020).

O Brasil seguiu uma linha similar aos Estados Unidos, sem uma ação unificada e com medidas tomadas por governos estaduais competindo com declarações públicas do presidente da República, que
6 Data de fechamento do trabalho. Neste período, o Brasil e a América Latina constituíam-se como epicentro da crise global, com número de casos em linha ascendente. Países europeus e estados chineses voltavam às políticas de quarentena. Não havia previsão de disponibilização de vacina até esta data.

7 APÓS DOIS MESES DE QUARENTENA NACIONAL, ITÁLIA INICIA RELAXAMENTO, 2020 


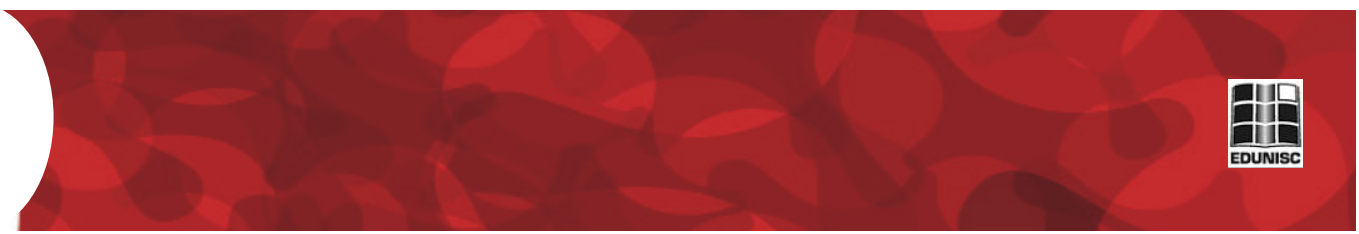

por se opor à restrição da circulação, atacou governadores, prefeitos e até ministros do Supremo Tribunal Federal (STF)(CHAIB; TEIXEIRA, 2020). Com isso, o Congresso chegou a iniciar a discussão de um Projeto de Emenda Constitucional que garanta que governos estaduais e prefeituras de capitais tenham direito de tomar decisões sobre casos urgentes de saúde pública, por formação de maioria absoluta (CHAIB; TEIXEIRA, 2020).

Em uma pesquisa de matriz histórica, Biernath (2020) resgatou um folheto de 1918, sobre a gripe espanhola, que avisava aos brasileiros para evitarem concentrações públicas, visitas, fadiga por exercícios e também informava para redobrarem hábitos de higiene e adotarem descanso, caso sentissem sintomas de resfriado. Tais recomendações levavam em conta o fato de que a transmissão ocorre de pessoa para pessoa, através de partículas expelidas por infectados. Contemporaneamente, se sabe que objetos que tenham sido atingidos por tais partículas também são fontes de contágio (MINISTÉRIO DA SAÚDE, 2020). Assim, com um menor contato físico entre pessoas, se reduz o número de infectados. Porém, a redução da circulação pública causa resistência, devido ao desaquecimento da economia. Essa resistência criou, em 2020, uma linha discursiva que tenta pautar um novo paradigma técnico, com a ideia de forçar uma "imunização comunitária" para acabar a epidemia de Covid-19, ou seja, deixar todo mundo se contaminar, como acontecia antes da existência de vacinas.

A historiadora Christiane Maria Cruz de Souza (apud BIERNATH, 2020) considera que há uma cronologia similar nas ações realizadas durante pandemias já vividas: primeiro, as autoridades negam; depois, se espalham dicas de supostas curas, como limão, alho e até cachaça; então, as pessoas praticam desobediência civil das regras impostas. A negação da existência da pandemia está na base de discursos estigmatizados, como a nomenclatura de "gripe espanhola" para uma doença cujo foco inicial não surgiu na Espanha, ou a tentativa de chamar o coronavírus de "vírus chinês".

Desde janeiro de 2020, quando se descobriu que a epidemia de infecção respiratória na China era causada por coronavírus e que havia uma potencialidade de crise global, houve grande disseminação de conteúdos falsos sobre o assunto. A partir de um aplicativo de denúncia de conteúdos falsos, a Fiocruz (2020) analisou os tipos de fake news que circularam no Brasil de março a maio. Na primeira fase, $20 \%$ das fake news eram sobre "métodos caseiros para prevenir o contágio da Covid-19, 5,7\% se referem a golpes bancários, 5\% fazem menção a golpes sobre arrecadações para instituição de pesquisa e 4,3\% se referem ao novo coronavírus como estratégia política". Na segunda fase, de 11 de abril a 13 de maio, dentre as fake news, "24,6\% afirmam ser a doença uma estratégia política, 10,1\% ensinam métodos caseiros 
para prevenir o contágio do novo coronavírus, $10,1 \%$ defendem o uso da cloroquina e hidroxicloroquina sem comprovação de eficácia científica e 7,2\% são contra o distanciamento social" (FIOCRUZ, 2020, online). O tipo de assunto permite perceber que o discurso de autoridades políticas tem um forte impacto na reverberação de conteúdos falsos.

A expansão de conteúdos falsos foi tanta que empresas jornalísticas intensificaram a cobertura midiática contra as fake news. O site de sátira jornalística Sensacionalista criou o grupo de Facebook chamado Caça Fake, em que convoca seus seguidores e fãs para ações de denúncia e derrubada de conteúdos falsificados na plataforma. Todos os dias, o administrador, ligado ao Sensacionalista, altera a postagem principal do grupo, convocando os membros para a ação: "Conseguiu remover uma hoje, 29/05? Cole o print aqui para atualizarmos o placar. Já removemos 341 posts" (SENSACIONALISTA; CAÇA AO FAKE, 2020). O grupo pode ser pensado como uma iniciativa de jornalismo cidadão, que aciona seus múltiplos públicos para exercerem papéis de cidadania em defesa da esfera pública (MERRITT, 1997).

Nas mídias sociais, até mesmo o presidente brasileiro teve postagens apagadas. “Após o Twitter, o Facebook também decidiu apagar publicação do presidente Jair Bolsonaro de suas plataformas, por entender que cria 'desinformação' que pode 'causar danos reais às pessoas"” (MARQUES, 2020, online). A publicação em questão se tratava de um vídeo em que o presidente causava aglomeração e não tomava cuidados para evitar disseminação do coronavírus. Outras empresas, como Google e Microsoft, também assinaram acordo para "combater fraudes e desinformação sobre o novo coronavírus" (MARQUES, 2020, online).

Embora o Twitter e o Facebook anunciem medidas restritivas de circulação de fake news, as ações implementadas pelo WhatsApp (da mesma empresa do Facebook) são escassas e menos eficazes. No começo de maio, a empresa anunciou um bot para combater fake news (FABRO, 2020), que compara resultados de 80 organizações de checagem de fatos, que funcionam em 74 países. Testamos o aplicativo no dia 29 de maio e ainda não havia a versão em português, anunciada no lançamento. $\mathrm{O}$ chat funciona pelo reconhecimento de números e símbolos digitados pelo usuário. Assim, toda a iniciativa para encontrar uma notícia falsa depende do usuário, ou seja, não acontece automaticamente pela plataforma. 


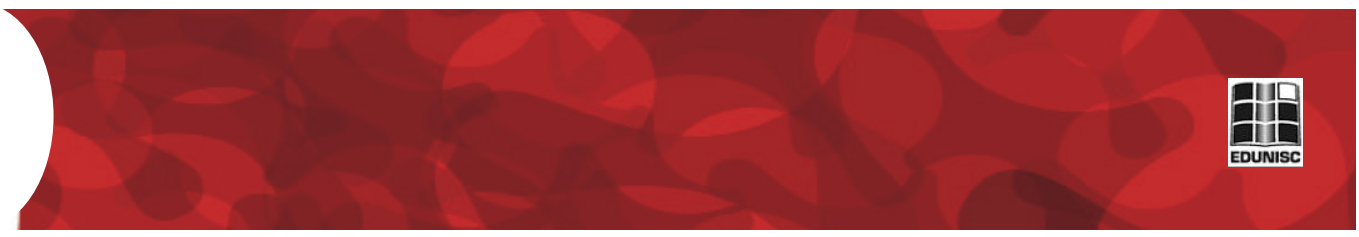

\section{Fake news compartilhadas em grupo de WhatsApp}

José Luiz Braga (2018, p. 40) sinaliza que "o esforço produtivo para circular se faz na conformação da escuta prevista ou pretendida", o que resulta na produção de contrafluxos, a partir de respostas e interações que, em mídias sociais, ficam registradas de vários modos nas plataformas digitais. Braga (2018) entende que se cria uma dimensão diferente da conversação em presença (que implica um mecanismo de ida e volta entre os participantes). As condições de registro e as interfaces sociais e digitais se encadeiam, causando um "fluxo contínuo, sempre adiante" (BRAGA, 2018, p. 40), que impede que se observem claramente pontos de partida e de chegada, ou papéis tão distintos, como os de emissores e receptores.

A indistinção de papéis e etapas transforma os regimes de acontecimentalização. Na projeção dos eventos na internet, se misturam manifestações diretas das pessoas com registros aleatórios de sua navegação, registros de preferências pessoais, experiências cotidianas com affordances de plataformas digitais, como o uso da hashtag, cuja apropriação pelos usuários está na base da geração de correntes de mobilização. Tais informações não estão necessariamente presentes na fala dos indivíduos, mas igualmente fazem parte da produção de eventos e reverberações na internet. Ao tratar de acontecimentos que se mesclam com as lógicas das redes sociais, com organização em rede, narrativas elaboradas pelos participantes, discussão pública instantânea, Henn (2013) classifica a ocorrência de "ciberacontecimentos", que acabam retornando ao jornalismo, pela intensa reverberação nas redes.

Notamos que os circuitos ao redor das fake news não necessariamente precisam atingir uma forma totalmente distinta dos demais eventos sociais, como seriam grandes ciberacontecimentos, como as manifestações de junho de 2013, iniciadas a partir de protestos por melhor transporte público, no Brasil (HENN, 2013). Por estarem diretamente ligadas com as experiências individuais das pessoas, as lógicas acontecimentais podem ocorrer em escala micro e ter impacto para públicos de nicho, ainda que não sejam imediatamente percebidas por outros públicos na mesma sociedade. É o que observamos em grupos do WhatsApp, plataforma que se tornou central na disseminação de informações e também de conteúdos falsos. Daí a pertinência em observar ações de usuários e tipos de conteúdos neste domínio.

Para a construção da análise, contamos com a contribuição de um informante, membro de um grupo, no WhatsApp, composto por profissionais da saúde, que nos remeteu todos os conteúdos que relacionavam a pandemia a ações e diretrizes políticas do governo brasileiro. Os materiais eram emitidos no grupo por três membros, sendo que um deles era mais ativo. Em algumas circunstâncias, 


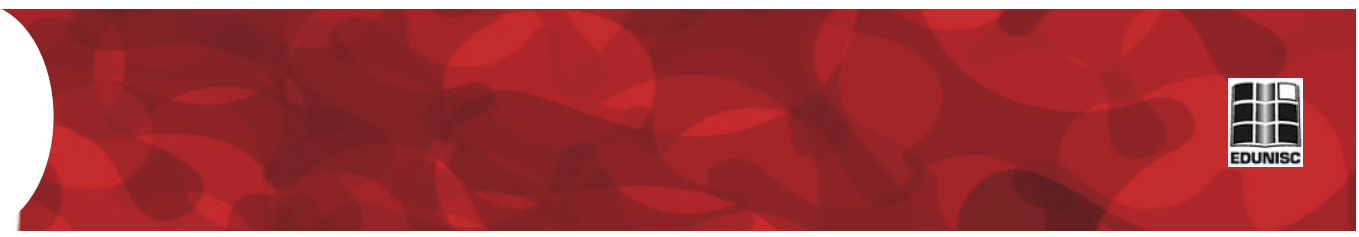

especialmente em casos de falas polêmicas do presidente, havia algum debate entre os membros (apenas nestes casos recebemos mostras de diálogos). Porém, desconsideramos as falas dos membros. O foco da análise são os conteúdos compartilhados e a forma como se correlacionam a circuitos de fake news e desinformação. A coleta foi feita entre 15 de março e 5 de maio. Há uma correspondência entre os pronunciamentos, as entrevistas, as lives do presidente, as redes de boatos envolvendo deputados da base governista e as ondas de dissipação de conteúdos no grupo de WhatsApp observado.

Vídeos, áudios, links e comentários são postados de acordo com o assunto reverberado por uma onda de conteúdos, que contempla tópicos de humor. É o caso de um vídeo que consiste na justaposição de uma fotografia de um ator com sua família, em uma grande piscina, com um áudio de uma pessoa que desabafa, em tom humorado, sobre as diferenças entre a quarentena dos ricos e dos pobres, que precisam fazer comida, lavar roupa, limpar casa e conter crianças o tempo todo. O conteúdo não é postado como brincadeira, mas com uma descrição que remete à onda de postagens sobre a abertura das atividades comerciais: "E esse vídeo abaixo vc vai saber porque temos que voltar a trabalhar mas claro tomando todos os cuidados". Na circulação geral de conteúdos, existem aqueles que figuram com função primeira de humor, como memes, um deles comparando o formato do coronavírus ao de uma planta brasileira conhecida pelo nome de "mamona". O conteúdo de humor é minoritário na amostra.

É curioso que, dentre os links postados, apareça uma única vez um link para a Tribuna do Norte, RN, sobre a desistência do governo estadual em fazer propaganda, e um link para um vídeo explicando o que seria o "isolamento vertical", postado pela BBC Brasil, em seu canal no YouTube. Nos dois casos, a seleção de notícias converge com a posição política de quem posta, isto é, pró-Bolsonaro e contra Fátima Bezerra, governadora do RN, do PT, partido de oposição a Bolsonaro. Há também um link que direciona para o Estadão, porém na seção de opinião, com texto intitulado "comunavírus", com postagem falando em "vírus chinês" e ícone da bandeira da China. Há um link para artigo de opinião no The New York Times, com comentário em português sobre mudança de postura de Trump. Todos os outros links são de canais e páginas de indivíduos e grupos não necessariamente vinculados ao jornalismo ou produção pública.

Observa-se uma ascensão de blogs e sites que misturam informação factual com opinião pessoal. Há links para blogs locais e até para página de bombeiros SP (tratando do avanço de governos conservadores). O blog de Isamel Sousa publica: "governadora do RN agora concorda com Bolsonaro e sinaliza reabertura das atividades econômicas". O tom é similar ao "Blog do BG". A afirmação carrega 


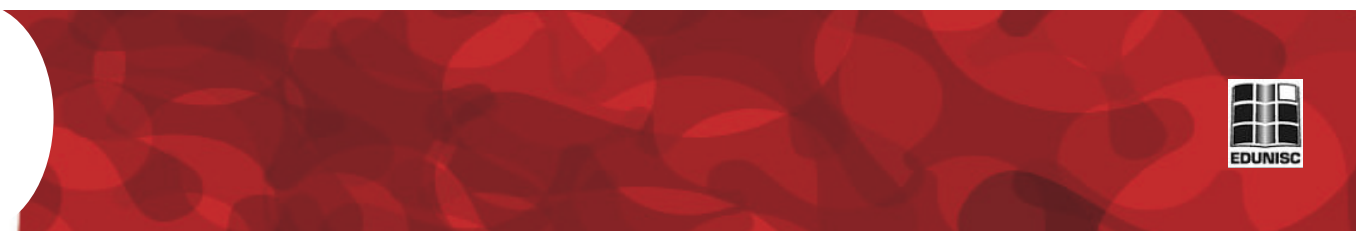

falseamentos, ao projetar a intenção ou pensamento de uma pessoa que não são manifestos por ações e falas. Situação similar ocorre com link para outro blog, que remete a uma síntese de fala do expresidente Fernando Henrique Cardoso, de que existe necessidade de um movimento popular, além de um motivo legal, para a realização de um impeachment. O texto do compartilhamento classifica o expresidente como "altamente envolvido com as trevas", o que o desqualifica. A opinião do interpretante remete à intenção/imaginação: "o medo da manifestação que ficou conhecida como 'o Dia do Fodase', tem deixado os inimigos políticos do presidente [Bolsonaro] aterrorizados".

A assinatura mistura: a) a desinformação e o falseamento das posições de pessoas com pensamentos divergentes (diretamente ligados à noção de fake news), b) opinião que se coloca como verdade sobre o mundo, c) e uma organização militante, convocatória, com adição de assuntos religiosos. "Esquerda comunista/globalista recua mais uma vez diante da nação brasileira... diante do povo de Deus". Também se constrói uma posição moralmente boa e correta para o falante, além da menção a fatos que não aconteceram.

Alguns conteúdos aparecem em diferentes formatos, como um vídeo que contém uma entrevista feita por Datena a um profissional que trata o uso da hidroxicloroquina em uma paciente de 72 anos como "esperança", "notícia boa" a ser comemorada. O conteúdo é depois replicado em outro vídeo, de um canal que trata do uso do medicamento em 500 pacientes, pela empresa Prevent Senior. O vídeo é compartilhado com a dica: "caso sintam os sintomas, enviem esse vídeo ao seu médico e peçam que ele faça a prescrição imediata, isso pode salvar a sua vida!". Adiciona que "adotar o remédio de forma tardia não adianta mais, $50 \%$ dos pacientes que são [dão] entrada na UTI vão a óbito". A afirmação da administração medicamentosa em fases precoces está presente em áudios e vídeos atribuídos a médicos, que chegaram a este mesmo circuito de WhatsApp.

$\mathrm{Na}$ amostra analisada, está presente a ideia de texto-imagem. Esta ideia também pode ser observada em outros circuitos de difusão informativa no WhatsApp (KLEIN, 2020). Dois destes materiais remetem a cards, folhetos digitais criados por assessorias, uma do deputado Eduardo Bolsonaro, outra do deputado General Girão. A primeira postagem diz: "Presidência da câmara impede votação que destinaria fundão eleitoral ( $\mathrm{R} \$ 2$ bilhões) e fundo partidário para combater o coronavírus". A primeira conecta-se com uma onda de conteúdos que também ancora falas generalistas sobre "políticos" e "partidos", sendo interessante notar que apesar de emitidas por políticos, estes parecem não se considerar como tais. Embora a referida proposta realmente não tenha sido votada, o post não explica que 


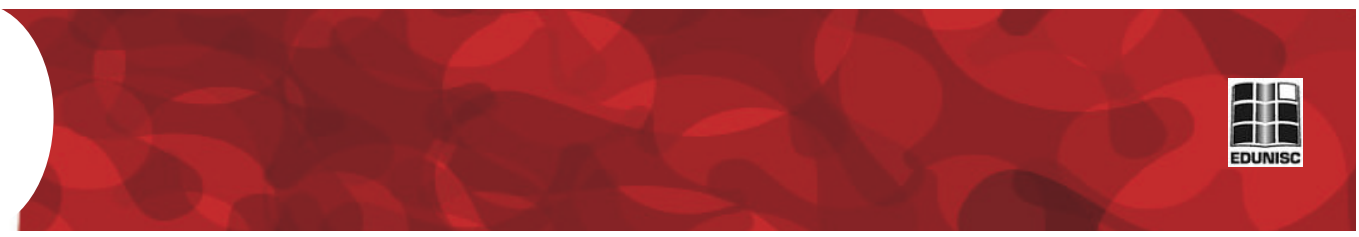

houve um argumento técnico na decisão da mesa. A segunda postagem diz que há um "golpe armado" e que o "PT quer cassação da chapa Bolsonaro/Mourão para forçar nova eleição para presidente e vice", embora isso seja uma conjectura, sem base em ações ou falas públicas.

Há registros de frases de impacto com forma visual: "A tendência é o Covid-19 matar mais CNPJ do que CPF!! Triste realidade"; "Já pode chamar de mitocloroquina ou ainda tá cedo?". Os conteúdos estão conectados a ondas acontecimentais formadas pela correlação de opiniões políticas, fake news e desinformação: o fechamento de empresas como culpa de governadores que impuseram quarentenas e a recomendação política do uso de um medicamento.

Há cinco fotografias de tela (screen shots) de posts no Twitter, que já circulam editados, podendo igualmente fazer parte de um amplo ciclo de compartilhamentos. Um deles defende o pronunciamento do presidente Bolsonaro contra a quarentena e diz que as pessoas o interpretaram mal. Outro se refere ao uso de medicação. Há mais um que defende pronunciamento e adiciona um componente de ataque à China presente em outras posições públicas dos presidentes do Brasil e dos Estados Unidos: "Well, como dizia Bolsonaro: a China não quer comprar do Brasil, quer comprar o Brasil". E, ao fim do período de coleta, outra fotografia de tela de tweet questiona a lealdade do exministro Sérgio Moro.

Há um conjunto de materiais que podem ser pensados como mensagem de texto para o WhatsApp, em geral não se encontram publicados em outras plataformas, não remetem a conteúdo visual ou audiovisual externo, não são apresentados links. O conteúdo tende a ser opinativo, embora haja remissão a contexto e, por vezes, aos dados. É o que ocorre em relação à crítica ao emprego de verba para propaganda pelo governo do RN. Esta crítica contém dados de publicação oficial, mas também uma interpretação equivocada: a propaganda seria feita para divulgar ações de enfrentamento ao Covid-19, mas é tratada na mensagem como uma propaganda promocional do governo. Observase que o falseamento pode se apresentar de forma tênue, a partir de modalidades de opinião e interpretação expressas em críticas.

Há uma maior ocorrência de conteúdos totalmente falsos neste tipo de material. "Dias Toffoli presidente do STF, Rodrigo Maia presidente da Câmara e Davi Alcolumbre e os chefes de partidos de esquerda entre eles PSDB com Aécio Neves e PT e PCdo B e Psol, se reuniram e fizeram um pacto com alguns governadores como João Doria de Sp e Wilson Witzel do RJ entre outros". Nota-se que o PSDB é apresentado como partido de esquerda, sendo que nunca se colocou deste modo na cena política do país. Aparece a rejeição à Câmara e ao STF, a partir de uma relação entre partidos e pessoas que não é expressa em evidências concretas. Em outra mensagem, é feita uma 


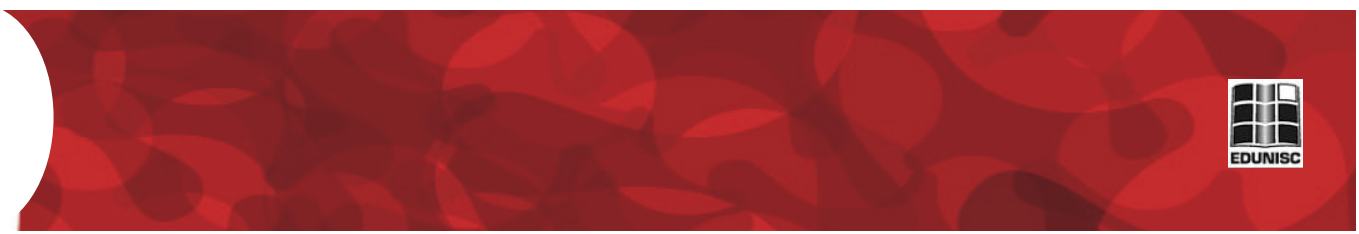

acusação de que o coronavírus foi buscado pela esquerda para resolver a perda de eleições no mundo. "Depois que Trump ganhou a eleição no ano de 2016, George Soros foi na mídia e disse: 'Trump é a pedra no sapato para nova ordem mundial"”. Outro trecho: "Com a ação em curso um novo espaço será aberto para a esquerda assumir o controle, colocando um socialista ou comunista a frente do país, firmando assim um plano global que está em curso". A declaração de George Soros nunca existiu, bem como não existe uma frente formada para ascensão do comunismo no Brasil.

O teor agressivo é repetido em boa parte destas mensagens. Em um longo trecho que classifica quem cumpre o distanciamento social como hipócrita, observa-se a acusação: “\#hipocritas além de FALIR o PAIS vamos todos morrer seus idiotas.. sem dinheiro vc fica sem remédio sem comida". Outro texto, também como crítica a quem cumpre distanciamento social, repete o tom: "Me irrita essa frase "estamos no mesmo barco'. Não, não estamos. Não seja ridículo. Estamos na mesma tempestade, mas não no mesmo barco". Tais textos colocam em oposição pessoas que fazem home-office versus pessoas que catam lixo. Em outros materiais, tal oposição é feita entre pobres e atores da Globo. O teor crítico das oposições cria uma ideia de defesa das pessoas com maior vulnerabilidade, que seriam favorecidas com o fim da quarentena. Não há, nestes textos, uma indicação de interferência do governo para reparação da situação destas pessoas vulneráveis.

O teor militante está igualmente presente em convocatórias para a ação do leitor, com mensagens nacionalistas unidas a trechos bíblicos. É pertinente notar que convocam a construção de uma audiência à parte do circuito midiático, tomado como oponente. "Vai ter uma live no YouTube hj as 20:30h do jornalista Oswaldo Eustáquio, vai ter revelações muito importante é vai ser justamente na HORA que o Moro vai ser entrevistado na Globo, vamos derrubar essa audiência dela e acompanhar essa live... se tiver interesse, repasse pra o maior números de pessoas" (dia 26/04). O alarme para espalhamento é claro: "BOMBA!!! DIVULGUE". O mais curioso deles ensina a burlar envios massivos no WhatsApp e termina com a frase: "REPASSEM ESSAS INSTRUÇÕES PARA QUE TODOS APRENDAM A FORMA DE SAIR DESSA CENSURA IMPOSTA PELO WHATSAPP”.

Háinsinuações que parecem extrapolaros limites da razoabilidade e até legalidade, como nos seguintes trechos, de diferentes postagens: "Adélio ligado a PCC e PSDB? Fraude nas eleições? Investigar algo do Doria na lava covid???????"; "MINISTRO DO STF ALEXANDRE DE MORAES É UM DOS PIORES CRIMINOSOS DO BRASIL"; "Entendem agora porque que o Alexandre de Moraes não quer que o Bolsonaro nomeie o chefe geral da Polícia Federal? Por que senão a segunda maior fonte de lavagem de dinheiro do PCC e do Foro de São 


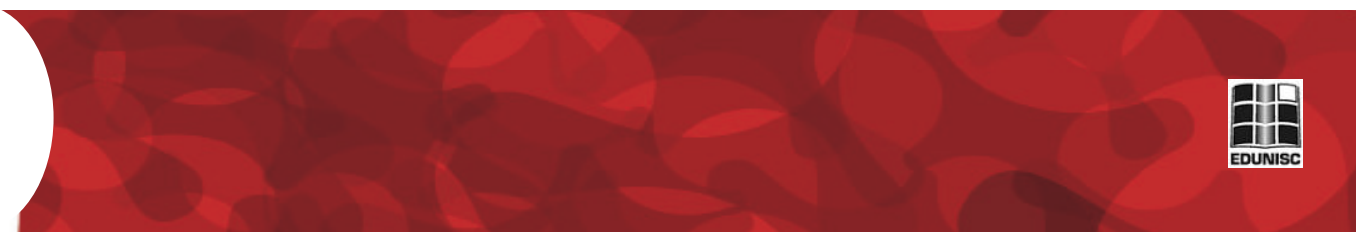

Paulo vai secar". A mais perigosa das insinuações ameaça membros do judiciário: "O pt e seus associados estão utilizando sua última bala: o stf. Para eles, o CAPITÃO tem a 'BALA DE PRATA'”.

$\mathrm{Na}$ amostra, foram coletados dois áudios cujos autores se designam como médicos. No primeiro, o falante diz que não tem casos graves onde trabalha e critica que crianças estejam em casa: "Sabe que zero a dois anos a chance de morte é de um em mil, esses tinham que estar na rua, para quê? Para se contaminar e criar resistência. Não estão, tão tudo trancafiado. Não pode se comparar com Europa. Brasil é um país grande, país quente e não vai acontecer o que estão falando". Este áudio se inicia com uma referência direta ao pronunciamento presidencial de 24 de março, ao qual é favorável, além de dizer que a mídia só se importa porque a doença começou com ricos, que se fosse com pobres, como a H1N1, a imprensa não iria fazer cobertura. É interessante notar que não há dados ou referências, mas apenas a preferência pessoal que, no entanto, é sustentada como perícia, pela atribuição do título profissional.

O segundo áudio, também atribuído a um médico, desaconselha o uso de máscara, pois o contágio em massa seria necessário para gerar "imunização comunitária". Além disso, afirma que os doentes seriam tratados com medicações conhecidas, referidas por seus nomes: "se essas drogas forem usadas de forma competente, por uma equipe de saúde treinada e ainda no início dos sintomas, na prática teríamos reduções nas internações e formas graves da doença”. Tais conteúdos geram um efeito de prova, de confirmação da realidade, quando em realidade são preferências e opiniões individuais expressas pelas pessoas.

Os vídeos são os materiais mais representativos na amostra, totalizando 30 conteúdos. Uma das categorias de vídeo é o relato de experiência pessoal. Uma marca destes vídeos é a apresentação da profissão: torneiro mecânico, motorista, vendedor de praia, apresentador de programa. $\mathrm{O}$ torneiro mecânico fala sobre quem vai brigar pelos filhos deles e da preocupação com a "vida financeira, porque tudo está parado". O vendedor de praia fala do litoral vazio e dos restaurantes fechados. O motorista fala da BR vazia e da dificuldade em achar comida, salienta que se os caminhões não circularem, médicos e enfermeiros também não vão ter como comer. Todos estes se colocam contra a mídia. Há uma repetição da ideia de apartidarismo. $\mathrm{O}$ apresentador de programa aparece como analista político e se coloca como "lulista", diz que votaria no ex-presidente Lula, se ele concorresse, mas defende a fala do atual presidente, Bolsonaro, afirmando que seria capaz de salvar o país da imposição de quarentena por governadores.

Os vídeos de médicos configuram uma categoria à parte, sendo 


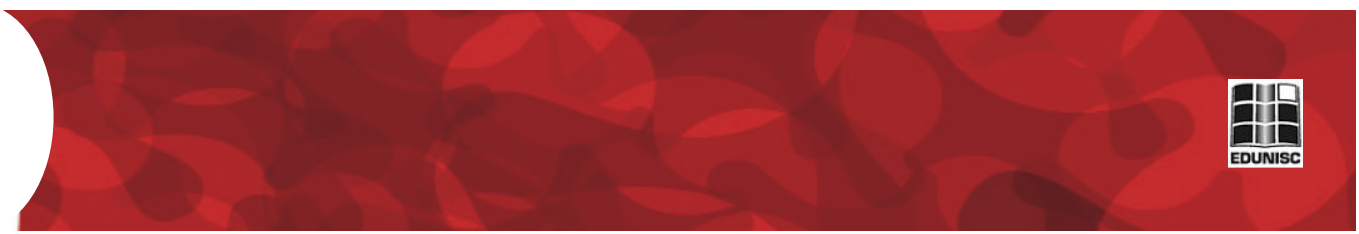

mesclada a experiência pessoal com a expertise nestes vídeos. Uma médica ordena parar de ver notícias sobre Covid-19 e "serenar", pois "o mundo não está acabando". Outro profissional de saúde trata de seu currículo e diz que não se envolve com política: "É preciso tomar decisões e destravar o país. Vão morrer pessoas? Vão. As pessoas dos grupos de risco realmente vão estar mais expostas, verdade. Mas e quantas pessoas também vão morrer de fome?". O vídeo termina com crítica a governadores e deputados. Em todos os vídeos de médicos, eles aparecem vestindo jalecos, às vezes, bordados com abreviaturas que remetem à palavra doutor/doutora seguida de nome. Em praticamente todos eles ocorre uma comum relativização da doença.

Outra categoria de vídeos contempla políticos que são apresentados como peritos. Um é o médico Osmar Terra, outro é o governador de Santa Catarina. Osmar Terra lista seu currículo como gestor, para definir seu próprio lugar como autoridade. "As pessoas que estiverem doentes têm que ficar confinadas, mas o restante da população tem que levar a vida mais normal possível. Isso não vai alterar uma pessoa que vai ficar doente, que vai morrer". O governador de Santa Catarina é apresentado, por quem posta, como alguém que atenua, mas confirma o que Bolsonaro apresentou no pronunciamento. Por fim, há um deputado que apresenta um projeto para usar o recurso de fundo eleitoral para construir leitos, pois "a maioria das mortes não se dá por agravamento da doença simplesmente, mas pela ausência de leitos de UTI". O deputado fala gritando, sem pausas, ataca o que chama de "os políticos" e "os partidos" e parece não se ver como um deles, mesmo quando usa pronome na primeira pessoa do plural.

Outra categoria de vídeos envolve montagens de conteúdos midiáticos e recortes de trechos de programas televisivos. Os recortes operam como um modo de construção de perspectiva, de orientação política. Um dos recortes mostra uma conversa entusiástica do apresentador Datena com o profissional do Prevent Seniors. Na ocasião da entrevista, a mãe do dono da companhia estava sendo tratada com o medicamento alvo da propaganda do presidente brasileiro e, segundo o profissional entrevistado, apresentava melhora. "Datena, a gente começa a literalmente criar uma esperança aí para o país e para todo mundo que precisa tratar estes pacientes". O nome do remédio é repetido várias vezes, sendo que o apresentador finge não saber falar corretamente, para ser corrigido e, assim, falar o nome mais uma vez.

Uma montagem apareceu três vezes, em diferentes formatos, apresentando um compilado de matérias sobre $\mathrm{H} 1 \mathrm{~N} 1$, realizadas na cobertura feita em 2009, entrecortadas com fala de Lula dizendo que o vírus parecia não ser da escala prevista e que o Brasil estava adotando medidas para se proteger. Tais vídeos circularam nas semanas seguintes ao pronunciamento do atual presidente em que 


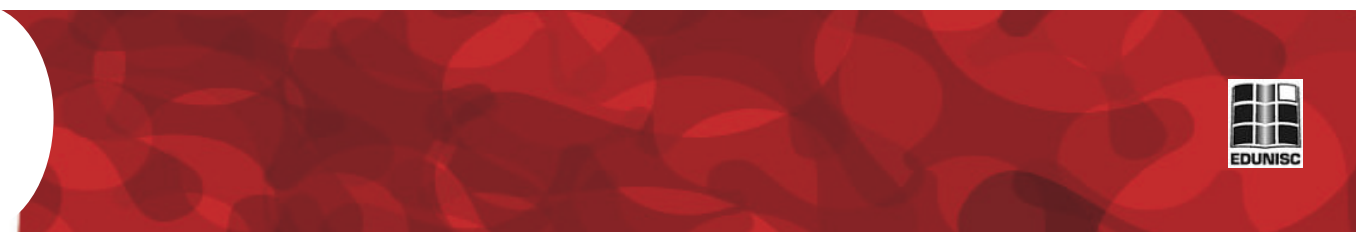

ele chama a Covid-19 de "gripezinha". Há uma tentativa de atenuar as críticas a Bolsonaro, comparando com a fala de Lula, sem que haja uma contextualização das variantes entre as epidemias, como a existência, à época, de vacina para H1N1. Outro grupo de montagens confronta a cobertura midiática com falas de médicos que defendem o fim da quarentena.

Uma montagem em vídeo simula as características do jornalismo profissional para um conteúdo falso, que vincula o vírus a uma tentativa de dominação comunista, sustenta que a China está preocupada em garantir o aborto no meio da pandemia e que o país aparelhou a Organização Mundial da Saúde. Além de a abertura ser feita com uma pessoa que ocupa o lugar de repórter (função atribuída por caracteres), o vídeo é entrecortado por fotografia de tela de publicações da mídia sobre a Covid (com sites reconhecidos, como El País e BBC, sobre casos em Wuhan e dúvidas sobre a doença), sendo que os últimos slides não são de mídias reconhecidas e mencionam defesa do aborto. A junção de conteúdos diferentes é feita com um tom de alerta, de aviso. Similar estratégia de edição é feita por uma pessoa que reclama ter que pagar contas de água e luz, quando os governos receberam ajuda federal.

Imagem 1: Imagem de tela de dois vídeos que usam estratégia similar de edição

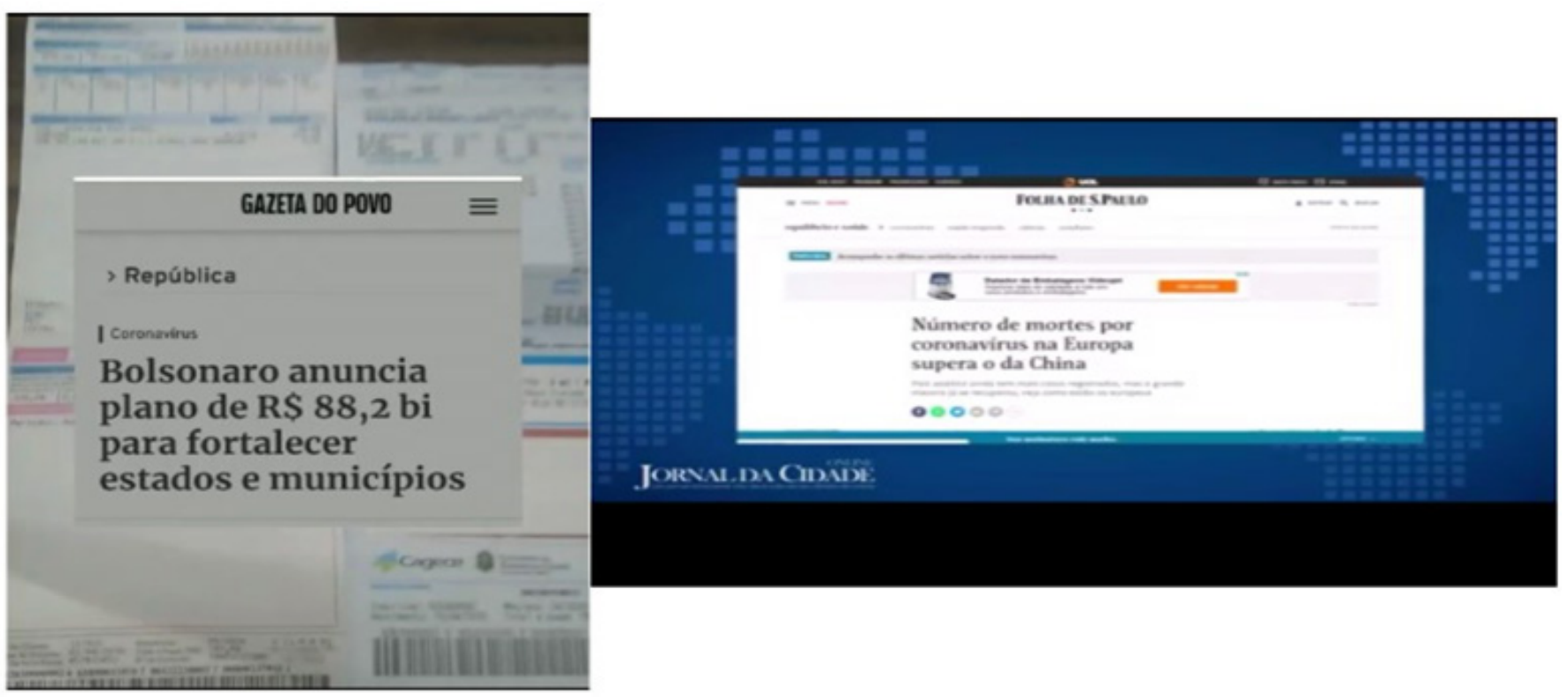

Fonte: Gazeta do Povo e Folha de S. Paulo

Em abril, uma onda de vídeos foi marcada pelo caráter denuncista, com pessoas indo a hospitais com câmera aberta, entrando em prontos atendimentos e dizendo que "não tem ninguém", não 

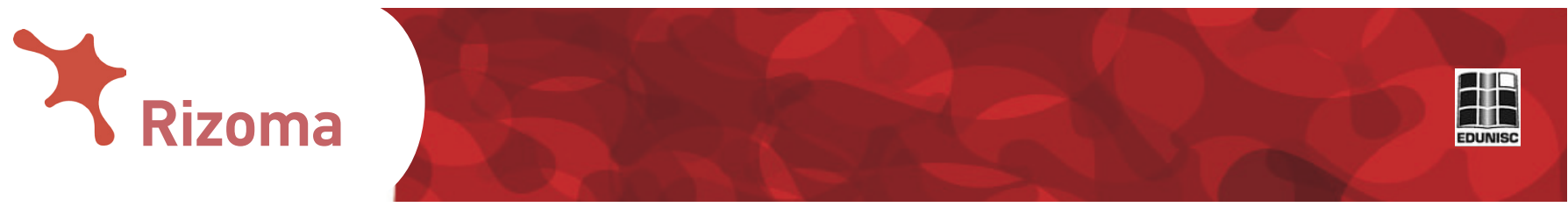

existe pandemia. Os vídeos simulam narração e tomadas feitas por reportagens televisivas, como aparecimento do narrador como repórter, texto explicativo acompanhando as imagens, uso de diferentes planos (geral, para dar noção do local, conjunto, para mostrar ambientes fechados e relação entre pessoas e objetos, médios para enquadrar pessoas). Há uma simulação de produtos jornalísticos, embora apenas se limite ao testemunho individual.

Imagem 2: Fotografia de tela de dois vídeos que buscavam provar que hospitais estavam vazios (rostos ocultados pela autora)
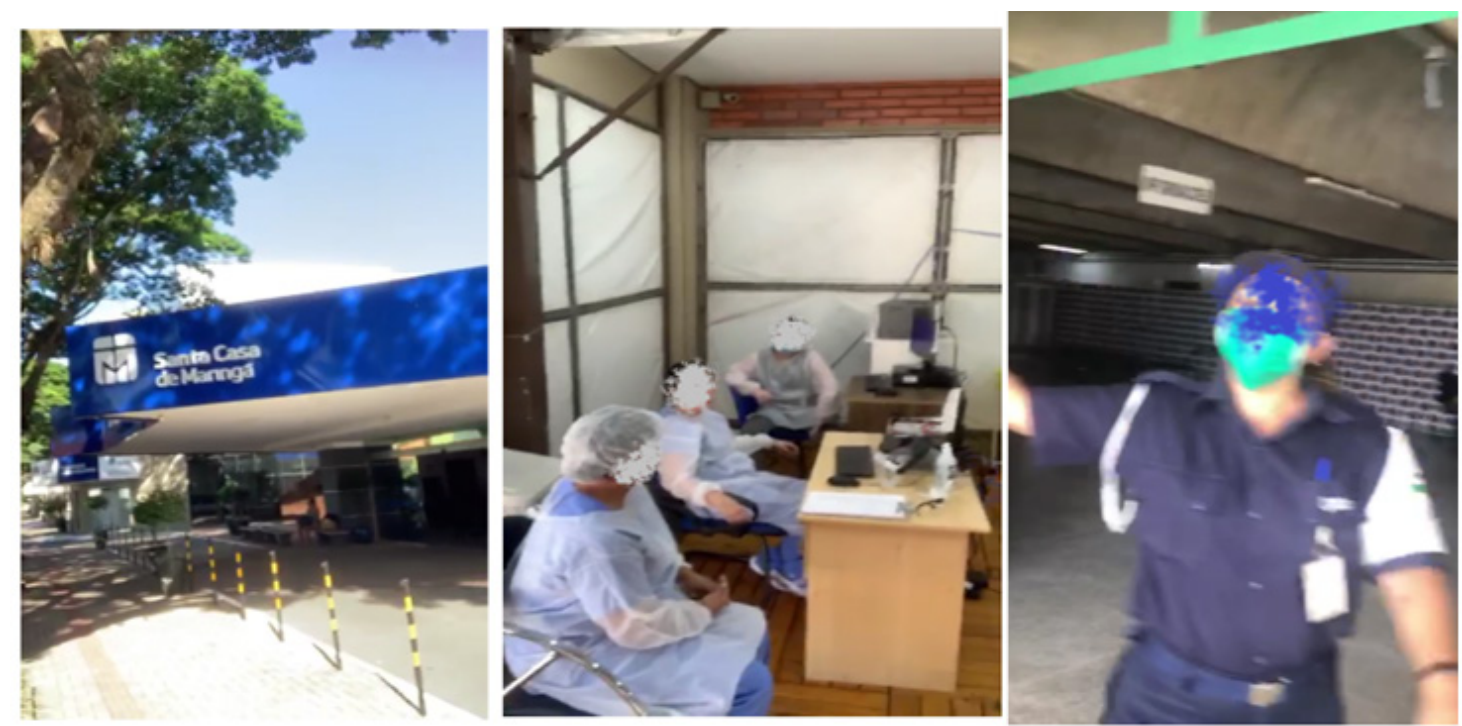

Fonte: redes sociais

Tais conteúdos circulam intensamente em 9 de abril, com lives públicas, e podem ser contextualizados a partir do "dia do jejum", em 5 de abril, quando evangélicos jejuaram para promover o dia de cura da doença e o presidente Bolsonaro ordenou que estados fizessem plano de abertura do comércio. Também foi a semana de pagamentos do auxílio emergencial, que gerou filas em frente às agências da Caixa Econômica Federal. Houve ainda uma nova live do presidente, em 8 de abril, minimizando os impactos da pandemia no país. Os quatro vídeos denuncistas têm narradores homens, que falam de forma exaltada. Um deles se declara como promotor e humilha a policial que tomava conta da entrada do hospital - e o colocou para fora diversas vezes. As agressões verbais, bem como o vídeo, só terminam quando um homem vestido como funcionário do hospital se aproxima na direção de quem gravava.

A existência de materiais derivados de colaboração dispersa denota, ainda, similitude a projetos de mídia alternativa, como a Mídia Ninja, no Brasil, que realiza cobertura de grandes eventos públicos a partir da ação midiativista de participantes. Esta audiência dispersa 
conclamada pelos chamamentos das mensagens de WhatsApp, pelos vídeos e áudios, se mostra ativa nestes vídeos. Ela também se revela ativa pelo constante repasse de tais materiais em alguns agrupamentos sociais mais amplos, como o grupo de WhatsApp onde os materiais aqui analisados foram postados.

\section{Considerações finais}

Há um modo de acontecimentalização próprio dos conteúdos falsos acerca dos eventos e das problemáticas sociais, que passa ao largo das instituições consagradas, como a ciência, a medicina, os órgãos internacionais, as instituições republicanas que seguem os padrões internacionais - e que são fontes preferenciais do jornalismo. Assim, observa-se que não há predileção pelo jornalismo institucionalizado e não há uma narrativa coesa, mas flutuações constantes nas perspectivas lançadas sobre eventos, falas, rumores e até sobre fatos.

Materiais distintos (imagens, vídeos, áudios, mensagens próprias para o WhatsApp) remetem a tópicos comuns. Vários conteúdos criticam governadores, dizem ser pessoas fora da política, mencionam fechamento do comércio como destruição da economia, recomendam remédios, pregam contaminação coletiva. Os materiais não são emitidos de modo aleatório, existe uma relação com cadeias de assuntos presentes em mídias sociais. No caso analisado, observamos as ondas de conteúdos ligados à crítica a governadores (após pronunciamento de Bolsonaro), o uso de remédios (após vídeos de Bolsonaro e entrevistas de Trump), a investigação de hospitais "vazios" (após questionamento do número de mortes e da não reabertura do comércio requerida pelo presidente).

A flutuação constante desafia as lógicas institucionalizantes. Não há repetição por um espaço de tempo suficiente para se criar uma sedimentação. Os circuitos se formam e se desfazem em temporalidades acontecimentais de ordem imediata, sem se apegarem às práticas sociais institucionalizantes e sem costurar narrativas próprias. Antes, se engajam em fragmentos de grandes narrativas, que vieram antes deles e irão prosseguir depois. Tais fragmentos remetem a emoções que são revividas a partir de comportamentos repetidos ao se tratar de tais narrativas estruturais, como a grande nação, o homem valente e o salvador. Porém, a emoção é parte da acontecimentalização efêmera. Se faz e se desfaz. Não se buscam parâmetros próprios, mas uma flutuação por fragmentos que se colam em várias correntes, simultaneamente.

Por fim, é importante ressaltar que é essencial vincular as noções de fake news e desinformação, posto que os conteúdos propriamente 
falsos se relacionam a outros modos de condução da discussão pública, como a confusão, a radicalização e a postura temperamental, a ordenação de ações pela insinuação de fatalismos, a reverberação de trechos de falas que soam interessantes à formação de uma onda discursiva.

\section{REFERÊNCIAS}

ALlCOTT, H; GENTZKOW, M; YU, C. Trends in the Diffusion of Misinformation on Social Media. Research an Politics. vol. 6 (2). Abr-Jun, 2019. Disponível em: https://journals.sagepub.com/ doi/10.1177/2053168019848554. Acesso em: 25 set 2020.

APÓS DOIS MESES DE QUARENTENA NACIONAL, ITÁLIA INICIA RELAXAMENTO. Veja, 2020. Disponível em: https://veja. abril.com.br/mundo/italia-inicia-nesta-segunda-relaxamento-daquarentena-nacional/. Acesso em: 25 set 2020.

ATIVISTAS QUE DENUNCIAM PUBLICIDADE EM SITES EXTREMISTAS CHEGAM AO BRASIL, Veja, 2020. Disponível em: https://veja.abril.com.br/mundo/ativistas-que-denunciam-publicidadeem-sites-extremistas-chegam-ao-brasil/. Acesso em: 25 set 2020.

BBC NEWS. Coronavírus nos EUA: 3 mudanças drásticas causadas pela pandemia no país que chegou a 100 mil mortos. UOL Economia, 2020. Disponível em: https://economia.uol.com.br/noticias/ bbc/2020/05/28/coronavirus-nos-eua-tres-mudancas-drasticascausadas-pela-pandemia-no-pais-que-chegou-a-100-mil-mortos. htm?cmpid=copiaecola. Acesso em: 25 set 2020.

BERMÚDEZ, Ana Carla. Precisamos aprender a não compartilhar desinformação. UOL, 2020. Disponível em: https:/educacao.uol. com.br/noticias/2020/02/10/desinformacao-leitor-tambem-tem-queter-responsabilidade-diz-especialista.htm. Acesso em: 25 set 2020.

BIERNATH, André. Coronavírus: o que podemos aprender com ele? Veja Saúde, 2020. Disponível em: https://saude.abril.com.br/medicina/ coronavirus-o-que-podemos-aprender. Acesso em: 25 set 2020.

André. Quais as semelhanças entre a Covid-19 e outras pandemias do passado? Veja Saúde, 2020. Disponível em: https://saude.abril.com.br/blog/tunel-do-tempo/semelhancas-covidpandemias-passado/. Acesso em: 25 set 2020. 
BRAGA, José Luiz. Circuitos versus campus sociais. Mediação \& Midiatização. Salvador: EDUFBA, 31-52, 2012. 403, 2012 . Disponível em: http://www1.pucminas.br/imagedb/documento/ DOC_DSC_NOME_ARQUI20180205111302.pdf. Acesso em: 25 set 2020. PUC Minas, 2018.

CAMPOS MELLO, Patrícia. Empresários bancam campanha contra o PT pelo WhatsApp. Folha de S. Paulo, 2018. Disponível em: https://www1.folha.uol.com.br/poder/2018/10/empresariosbancam-campanha-contra-o-pt-pelo-whatsapp.shtml. Acesso em: 25 set 2020 .

CHAIB, Julia; TEIXEIRA, Matheus. Ameaças de Bolsonaro a governadores e prefeitos mobilizam Supremo e Congresso. Folha de S. Paulo, 2020. Disponível em: https://www1.folha.uol.com.br/ poder/2020/04/ameacas-de-bolsonaro-a-governadores-e-prefeitosmobilizam-supremo-e-congresso.shtml. Acesso em: 25 set 2020.

CHAPARRO, Manuel Carlos. Jornalismo na fonte. In: DINES, Alberto; MAURIN, Mauro (org.). Jornalismo brasileiro: No caminho das transformações. Brasília, Banco do Brasil, 1996, p. 132-154.

QUEM É ALEKSANDR KOGAN, O PROFESSOR POR TRÁS DO ESCÂNDALO DA CAMBRIDGE ANALYTICA. Época Negócios, 2018. Disponível em: https://epocanegocios.globo.com/Tecnologia/ noticia/2018/04/quem-e-aleksandr-kogan-o-professor-por-trasdoescandalo-da-cambridge-analytica.html. Acesso em: jan 2019.

ESTADÃO. A Infodemia da desinformação. Estadão, 2020. Disponível em: https://politica.estadao.com.br/blogs/fausto-macedo/a-infodemiada-desinformacao/. Acesso em: 25 set 2020.

FABRO, Clara. WhatsApp anuncia bot para combater fake news sobre Covid-19. TechTudo G1, 2020. Disponível em: https://www. techtudo.com.br/noticias/2020/05/whatsapp-anuncia-bot-paracombater-fake-news-sobre-covid-19.ghtml. Acesso em: 25 set 2020.

FIOCRUZ. Estudo identifica principais fake news relacionadas à Covid-19. Informe Ensp, 2020. Disponível em: https://portal.fiocruz. $\mathrm{br} /$ noticia/estudo-identifica-principais-fake-news-relacionadascovid-19. Acesso em: 25 set 2020.

GENRO FILHO, Adelmo. O segrego da pirâmide: para uma Teoria Marxista do Jornalismo. Porto Alegre: Editora Tchê, 1987. 


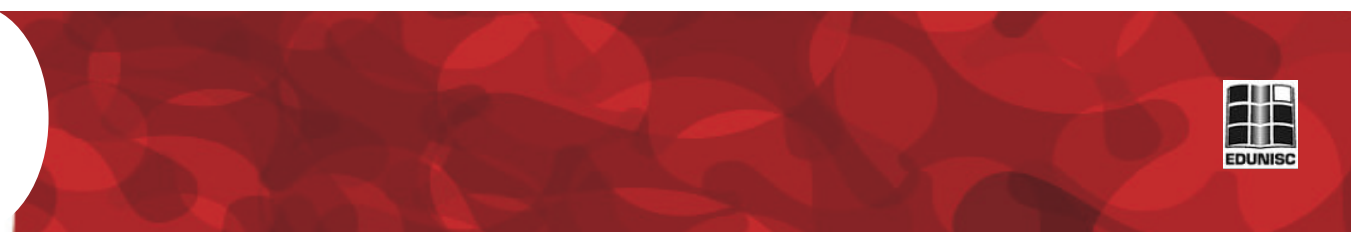

HENN, Ronaldo Cesar. Apontamentos sobre o ciberacontecimento: o caso Amanda Tood. Encontro Anual da Compós, 22., 2013, Salvador. Disponível em: http://compos.org.br/data/biblioteca_2068. pdf. Acesso em: 25 set 2020.

INSTITUTO MILLENIUM. A desinformação passou a ser usada como estratégia política. Exame, 2020. Disponível em: https:// exame.com/blog/instituto-millenium/a-desinformacao-passou-a-serusada-como-estrategia-politica/. Acesso em: 25 set 2020.

KLEIN, Eloisa. A propagação do texto-imagem no contexto de efemeridade e emoção em grupos de conversa no Whatsapp. VIII Colóquio Semiótica das Mídias, 2019. Disponível em: https://www. ciseco.org.br/images/coloquio/csm8/CSM8_EloisaKlein.pdf. Acesso em: 25 set 2020 .

MARQUES, José. Depois do Twitter, Facebook e Instagram também apagam post de Bolsonaro. Folha de S. Paulo, 2020. Disponível em: https://www1.folha.uol.com.br/poder/2020/03/ depois-do-twitter-facebook-tambem-apaga-post-de-bolsonaro.shtml. Acesso em: 25 set 2020.

MEDITSCH, Eduardo. O jornalismo como forma de conhecimento? Conferência proferida nos cursos de verão da Arrábida, Portugal, setembro de 1997. BOCC. Disponível em http://www.bocc.ubi.pt/ pag/meditscheduardo-jornalismo-conhecimento.pdf. Acesso em: mai 2020 .

MERRITT, Davis. Public journalism and public life: why telling the news is not enough. 2nd. ed. United States of America: Lawrence Erlbaum Associates, 1997. 151p.

MIGUEL, Rafa. Reino Unido prorroga quarentena até junho e anuncia regras a viajantes que entrarem no país por via aérea. El País. Londres, 2020. Disponível em: https://brasil.elpais.com/ internacional/2020-05-10/reino-unido-impora-quarentena-aosviajantes-que-entrarem-no-pais-por-via-aerea.html. Acesso em: $25 \mathrm{set}$ 2020.

MINISTÉRIO DA SAÚDE. O que é a Covid-19. Ministério da Saúde, 2020. Disponível em: https://coronavirus.saude.gov.br/sobre-adoenca. Acesso em: 25 set 2020. 
OPAS BRASIL. Folha informativa Covid-19. Organização PanAmericana da Saúde - Brasil, 2020. Disponível em: https://www. paho.org/bra/index.php?option $=$ com_content $\&$ view $=$ article $\& i d=610$ $1:$ covid19\&Itemid=875. Acesso: 25 set 2020 .

PIRES, Breiller. Com crescimento acelerado, Sleeping Giants irrita tropa de choque bolsonarista e Governo. El País, 2020. Disponível em: https://brasil.elpais.com/brasil/2020-05-23/com-crescimentorecorde-sleeping-giants-irrita-tropa-de-choque-bolsonarista-dentro-efora-do-governo.html. Acesso em: 25 set 2020.

RESENDE, Gustavo; MELO, Philipe; SOUSA, Hugo; MESSIAS, Johnnatan; VASCONCELOS, Marisa; ALMEIDA, Jussara; BENEVENUTO, Fabrício. (Mis)Information Dissemination in WhatsApp: Gathering, Analyzing and Countermeasures. International World Wide Web Conference Committee, 2019. San Francisco: ACM Press, p. 1-11, 2019. Disponível em: https://dl.acm.org/ citation. cfm?id=3313688. Acesso em: 25 set 2020 .

SPAGNUOLO, Sérgio. Whastsapp as a tool for news: lessons from Brazil's 2018 election. Relatório de mídia. Junho, 2019. Disponível em: https://www.icfj.org/sites/default/files/2019-06/WhatsApp\%20 as\%20a\%20tool\%20for\%20news.pdf. Acesso em: 25 set 2020.

TANDOC JR, Edson C; LIM, Zheng Wei; LING, Richard. Defining "fake news". A typology of scholarly definitions. Digital journalism. Londres, Reino Unido: Routlegde, Taylor \& Francis group, 2017. Disponível em: https://www.researchgate.net/publication/319383049 Defining_Fake_News_A_typology_of_scholarly_definitions. Acesso em: 25 set 2020 .

VALENTE, Jonas. Especialista diz que não há "solução mágica" para combater fake news. Agência Brasil, 2019. Disponível em: https://agenciabrasil.ebc.com.br/geral/noticia/2019-07/especialistadiz-que-nao-ha-solucao-magica-para-combater-fake-news. Acesso em: 25 set 2020 . 